\title{
Juridificeringen af amerikansk udenrigspolitik
}

Helle Porsdam

Der er næppe det politiske spørgsmål i USA, som ikke på et eller andet tidspunkt bliver omdannet til et juridisk spørgsmål, skrev Tocqueville i sin berømte bog Democracy in America. Udviklingen synes at give ham ret

"Ved du, at højesteretsdommer Antonin Scalia kommer til byen?", spurgte en af mine studerende for nogle uger siden i en mail.

Det vidste jeg godt, for jeg skulle være sammen med samme Scalia ved en konference i Lund i dagene op til hans besøg på Københavns Universitet - men jeg var rigtig glad for at høre, at mine studerende var klar over, han skulle komme. Jeg havde nemlig i efterårssemesteret 2008 undervist et kursus for historiestuderende på SAXO-Instituttet, Københavns Universitet om amerikansk retshistorie, og derfor kunne Scalias besøg ikke komme på et bedre tidspunkt.

Min disciplin hedder 'Amerikanske Studier', og det, vi amerikanister interesserer os for, er amerikansk kultur og historie bredt forstået. Jeg har nogle gange undervist i amerikansk historie gennem en retlig vinkel - altså taget de briller på, der hedder konstitutionel historie.

På denne måde mener jeg, at det er muligt at give ny studerende, der måske ikke har beskæftiget sig så meget med USA, et glimrende indblik i de normer og værdier, som amerikanerne holder i hævd, og som udgør det, nogle kritikere har refereret til som den amerikanske 'civile religion.' Det er i denne civile religion, vi skal tage vores udgangspunkt. Eftersom det retlige - troen på retssamfundet eller the rule of law - udgør en stor del af denne civile religion, vil den dømmende del af det amerikanske magtapparat og i særdeleshed den del af dette, som højesteretsdommer Scalia repræsenterer, nemlig den amerikanske 
Højesteret, komme til at spille en stor rolle i det følgende.

USA er et i bund og grund retliggjort samfund. Og når man i dag taler om en global ekspansion af $j u$ diciel magt, så er der ikke megen uenighed om, at denne ikke mindst skyldes en påvirkning fra USA.

"If any nation is the peculiar home of the expansion of judicial power, it is the United States," som Martin Shapiro så rammende formulerer det. Som Shapiro og andre ser det, har juridificeringen af den politiske sfære dels noget at gøre med overførselen af beslutningstagende myndighed fra politiske fora (parlamenter, regeringer, administrationer) til retlige fora (domstolene) og dels med spredningen af en retlig måde at træffe beslutninger og at diskutere problemer på til ikke-retlige fora. Det bredest mulige argument for en sådan juridificering er, at en forfatning og/eller de universelle menneskerettighedsdokumenter indeholder et sæt sikre og identificerbare rettigheder, som ikke umiddelbart bør kunne stemmes væk ved en flertalsbeslutning. Flertallet har ikke altid ret, og det er vigtigt, at disse kernerettigheder beskyttes for fx minoriteter af domstolene, dersom flertallet skulle finde på at ville af med dem.

Amerikansk historie er fuld af mindretal, der har måttet gå rettens vej for at få håndhævet netop deres rettigheder, fordi flertallet ikke var til sinds at afgive magt til disse mindretal.
Jeg oplever igen og igen, når jeg underviser i eller er ude at holde foredrag om USA, at folk udmærket godt ved, hvad det er, jeg sigter til, når jeg taler om amerikansk retliggjorthed og om den rolle, juraen og juristerne spiller i amerikansk sammenhæng. Og hvorfor gør de det? Jo, simpelthen fordi godt og vel 70 pct. af de film, dansk fjernsyn sender, er af amerikansk oprindelse, og fordi en god del af disse amerikanske film har jurister med i hovedrollerne og desuden har et dramatisk klimaks, som foregår i en retssal.

Vi er simpelthen i Danmark helt vant til at høre amerikanere sige "I'll see you in court," og vi ved, at dette med at få sin dag i retten anses for at være en af de vigtigste demokratiske rettigheder på den anden side af Atlanten. Harvard-forskeren Joseph Nye talte for nogle år siden om amerikansk (populær) kultur som 'soft power' - det er ikke mindst via sine kulturelle produkter, at amerikanerne effektivt får spredt deres budskab om troen på retssamfundet og det fortræffelige i lige netop deres variant af demokratiet: det konstitutionelle demokrati.

"In America," som en af ideologerne bag den amerikanske revolution Tom Paine i sin tid formulerede det, "the law is king!"

Vi vil som sagt starte med den amerikanske civile religion og den rolle, som juraen og juristerne spiller heri. Dernæst vil det være højesteretsdommer Scalia og hans kol- 
leger i den amerikanske Højesteret og den måde, hvorpå de er med til for øjeblikket at juridificere udenrigspolitikken, der vil stå i centrum. Og slutteligt vil vi vende os mod et af de mest aktuelle eksempler på en sådan juridificering af den amerikanske udenrigspolitik, nemlig Guantanamo-lejren på Cuba og den behandling af formodede terrorrister, som foregår der.

\section{En politisk religion}

I en af sine første politiske taler var Abraham Lincoln, der senere skulle blive USA's 16. præsident, inde på, at USA har en 'politisk religion,' og at denne religion har noget at gøre med 'ærefrygt for lovene':

"Lad hver amerikaner, hver elsker af friheden, hver person som ønsker godt for sin eftertid, sværge ved det blod, der blev udgydt under [den amerikanske] Revolution, aldrig nogensinde at overtræde landets love; og aldrig at tolerere, at de overtrædes af andre. Som patrioterne fra 1776 gjorde for støtten til Uafhængighedserklæringen, sådan bør også hver amerikaner forpligte sit liv, sin ejendom og sin hellige ære på at støtte Forfatningen og Lovene;... Lad ærefrygt for lovene blive hvisket af hver amerikansk mor til hendes spæde baby, der pludrende leger på hendes skød - lad den blive videregivet i skoler, seminarer og colleges; lad den blive nedskrevet i ABC'er, stavebøger og almanakker; lad den indgå i prædikener, blive bekendtgjort i lovgivende fora og blive opretholdt i retssale. Lad den kort sagt blive nationens politiske religion; og lad gamle såvel som unge, rige såvel som fattige, alvorlige såvel som muntre af alle køn og tungemål, farver og forhold uafladeligt ofre på dens altre."

Lincoln var blot 28 år gammel, da han den 27. januar 1838 holdt sin Lyceum Address. Netop denne tale gjorde sit til at gøre ham berømt ud over Illinois' grænser, og folk henviser ofte til den, når de skal forklare, hvad amerikansk 'civil religion' er for en størrelse. Begrebet blev i den amerikanske kontekst 'opfundet' af den amerikanske sociolog Robert Bellah i artiklen Civil Religion in America fra 1967, i hvilken Bellah gjorde gældende, at amerikanerne går ind for en civil religion med visse fundamentale anskuelser, værdier og ritualer, som er parallelle med, men alligevel uafhængige af deres foretrukne religion.

I religionssociologien har man efterfølgende talt om den civile religion som en nations folkelige eller politiske religion. Eksempler herpå kan være den måde, hvorpå Gud nævnes og/eller Biblen citeres i politiske taler; den måde, hvorpå Guds navn figurerer på offentlige bygninger; den måde, hvorpå afdøde politiske ledere og deres moralsk-etiske idealer omtales med ærbødighed og den særlige rolle, som en nations myter - i USA navn- 
lig landets 'founding myths' - spil-

ler. Her er der tale om, hvorledes religiøse eller semi-religiøse emner blandes med politiske emner. Vi behøver blot at tænke tilbage på Barack Obamas indsættelse som ny amerikansk præsident i januar 2009 - her blev USA's 'founding myths' og landets politiske ideologi og særlige rolle nævnt side om side med bibelske citater og andre henvisninger til Gud.

Politiske kommentatorer og journalister har dog også brugt begrebet 'civil religion' om visse rituelle og patriotiske praksisser, som ikke nødvendigvis indebærer noget religiøst. Oprindeligt stammer det fra en af Oplysningstidens store tænkere, Jean Jacques Rousseau. Det blev ikke brugt direkte af den amerikanske forfatnings fædre, men lå ikke desto mindre i luften i det intellektuelle klima, som herskede omkring dem. Således skrev bl.a. den franske aristokrat Alexis de Tocqueville i sin berømte bog Democracy in America, at størsteparten af de folk, han havde mødt i Amerika, ikke var til sinds efter at have rystet pavens autoritet af sig at ville anerkende nogen anden religiøs overhøjhed. De havde taget en form for kristendom med sig, som Tocqueville mente, man bedst kunne betegne som en demokratisk og/eller republikansk religion.

Tocqueville var fransk aristokrat, og det interesserede ham at finde ud af, hvad 'demokratiet' var for en størrelse - og om denne nymodens opfindelse måske var noget, man skulle tænke på at lade sig inspirere af i Europa. Han rejste derfor rundt i USA, gjorde grundige studier i marken og skrev dernæst sine iagttagelser ned. Disse var så skarpe og rammende, at Democracy in America hurtigt blev en klassiker, og i dag kan man slet ikke beskæftige sig med amerikansk demokrati og det amerikanske politiske system uden at have Tocqueville med. En af de mest berømte passager i bogen drejer sig om den rolle, som jurister og det juridiske system spiller i USA:

"Der er næppe det politiske spørgsmål i USA, som ikke på et eller andet tidspunkt bliver omdannet til et juridisk spørgsmål. Det er derfor sådan, at partipolitiske spørgsmål diskuteres i et sprog, der er lånt fra juridisk sprogbrug og juridiske begreber. Da de fleste offentligt kendte mænd er eller har været jurister, bruger de deres juridiske måde at tænke på i varetagelsen af deres erhverv. Jurier gør alle klasser bekendte med denne juridiske måde at tænke på. Så den juridiske sprogbrug er blevet en del af den daglige sprogbrug; lovens ånd... gennemsiver samfundet helt ned til de laveste niveauer, indtil hele folket til slut er blevet smittet med dommerens smag og måde at se tingene på... I USA udgør juristerne en magt, som ingen frygter, fordi ingen er opmærksom på den".

For Tocqueville udgjorde altså ju- 
raen og juristerne en væsentlig del af den særligt amerikanske demokratiske og/eller republikanske religion - det, senere iagttagere skulle komme til at kalde den amerikanske civile religion. Det er den dag i dag sådan, at godt og vel to tredjedele af politikerne i den amerikanske Kongres er jurister af uddannelse, og at vejen ind $\mathrm{i}$ amerikansk politik typisk går over jurauddannelsen. For disse 'public servants' er det helt naturligt at benytte sig af det, den amerikanske juraprofessor Mary Ann Glendon engang kaldte 'rights talk' - altså en juridisk måde at tænke og udtrykke sig på. Og for den menige amerikaner er som tidligere næevnt en af de mest demokratiske af alle demokratiske rettigheder retten til at få 'one's day in court' - det er til domstolene, mange, ikke mindst etniske minoriteter, i tidens løb er gået for at få deres forfatningssikrede rettigheder anerkendt. Det er derfor de amerikanske domstole - med Højesteret i spidsen - der har været med til at bestemme, hvad det egentlig vil sige at være amerikansk. $\mathrm{Og}$ det er stadig sådan, at når der tales identitet i amerikansk sammenhæng - og det gøres der ofte i dette multietniske land - så er det juraens sprog, der bruges. Det juridiske system er en af de få ting, alle amerikanerne har tilfælles; man kan tale om juraen som en form for kulturlim - og om det juridiske system som et af de få steder, man kan forsøge at finde konsensus omkring det, USA står for.

\section{Højesteret og udenrigspolitikken}

Den amerikanske Højesteret er ikke blot med til at skabe fælles kulturelt fodslag i USA. Den er også en af de mest magtfulde størrelser i det amerikanske politiske landskab. Dette skyldes ikke mindst prøvelsesretten - at Højesteret kan erklære love, der kommer fra Kongressen, for forfatningsstridige. Prøvelsesretten er ikke nævnt i forfatningen; det var Højesteret selv, som tiltog sig denne magt i 1803. I sagen Marbury $v$. Madison erklærede højesteretspræsident Marshall simpelthen, at det fra nu af ville være Højesteret og ikke Kongressen, der havde beføjelse til at fortolke forfatningen. Der skulle gå mange år, før Højesteret for alvor begyndte at gøre brug af prøvelsesretten. Først i 1950'erne blev den et politisk redskab.

Hvad nu med udenrigspolitikken? Traditionelt set har Højesteret givet præsidenten - som 'commander in chief' - stort råderum til at føre den udenrigspolitik, han anså for at være den rigtigste. Og hvor Kongressen explicit har giver præsidenten bemyndigelse, har Højesteret slet ikke villet blande sig i præsidentens udenrigspolitiske dispositioner. Dette kan dog være ved at ændre sig. Et af de mest interessante konstitutionelle problemer for øjeblikket drejer sig om USA's forhold til den internationale verdensorden, og Højesteret synes at være blevet en vigtig kampplads, når der skal udkæmpes 
presserende udenrigspolitiske kampe. "Hver generation får den Forfatning, den fortjener," skrev juraprofessor Noah Feldman fornylig i en artikel i New York Times. "Efterhånden som tidens mest centrale problemstillinger finder vej til og igennem det juridiske system, bliver det Højesterets tur til at give sit besyv med, og ni dommere i kapper bliver orakler med hensyn til vores nationale identitet."

De konstitutionelle problemer, der knytter sig til den internationale verdensorden, kan inddeles i forskellige kategorier. Der er helt almindelige praktiske spørgsmål, såsom fx hvilken rolle den maritime ret skal spille. Dernæst spørgsmål af mere symbolsk karakter, som $\mathrm{fx}$ hvorvidt højtstående amerikanske embedsmænd kan anklages for forbrydelser mod international ret. Hertil kommer spørgsmålet om, hvilken status international ret overhovedet har og bør have i forhold til amerikansk ret sådan helt generelt og mere konkret, hvorvidt Genevekonventionerne gælder for folk, som af den amerikanske regering anses for at være terrorrister. $\mathrm{Og}$ slutteligt hvorvidt det er i orden endda måske ønskeligt - at Højesteret lader sig inspirere af udenlandske dommere og deres domme, når den fortolker forfatningen. Her må man alt i alt sige, skriver Feldman, at Højesterets domme er blevet "en de facto del af amerikansk udenrigspolitik. Ligesom Uden- rigsministeriet og Pentagon foretager Højesteret nu afgørelser i sager, som direkte ændrer og skaber landets forhold til resten af verden. $\mathrm{Og}$ når dommerne afsiger dom $\mathrm{i}$ disse sager, gør de ligeså meget som andre for at afgøre Amerikas skæbne i en tidsalder præget af global terror og økonomisk krise."

Hvorvidt denne juridificering af udenrigspolitikken nu er en ønskværdig udvikling, tager Feldman ikke som sådan stilling til. Han påpeger simpelthen, at som tingene nu er i USA, er Højesteret blevet en væsentlig spiller i udenrigspolitiske spørgsmål på ganske samme måde, som det er tilfældet i indenrigspolitiske spørgsmål. På dette tidspunkt er der brug for en amerikansk Højesteret, som engagerer sig i resten af verden og forholder sig aktivt til international ret. "Vi har brug for at bygge og ombygge alliancer - og retten har historisk været et af vores bedste redskaber til at gøre dette. I vores nuværende usikre situation ville det være en fatal fejltagelse at opgive vores historiske lederrolle i den globale spredning af retssamfundet (the rule of law)."

Man kan måske sammenfattende sige, at amerikanerne ikke kun synes at tolerere deres domstoles store politiske magt på det indenrigspolitiske område; de mener også, vi andre rundt omkring i verden vil have godt af en lignende juridificering!

Et af de mere konkrete spørgsmål, den amerikanske Højesteret er 
blevet bedt om at udtale sig om, og som har direkte udenrigs- såvel som indenrigspolitiske konsekvenser, er, om Geneve-konventionerne gælder for folk, som af den amerikanske regering anses for at være terrorrister.

\section{Guantanamo}

I den amerikanske fangelejr i Guantanamo Bay, Cuba, har Bushregeringen de forløbne år interneret hundrevis af fanger uden først at have anklaget dem for at have begået en forbrydelse og uden at have stillet dem for en dommer. Guantanomo var tænkt som en slags extra-juridisk zone for hærdede terrorrister, som man påstod ikke havde krav på den form for beskyttelse, Geneve-konventionerne ellers anses for at give til krigsfanger. Bushs jurister var endvidere af den opfattelse, at Guantanamo-fangerne ikke havde nogen ret som udenlandske statsborgere til at søge afklaring af deres situation i det amerikanske juridiske system, og at de kunne holdes indespærret ligeså længe, regeringen måtte ønske det.

Højesterets indgriben er et af de bedste eksempler på juridificeringen af amerikansk udenrigspolitik. I juni 2004 erklærede Højesteret i sagen Rasul v. Bush, at de udenlandske fanger i Guantanamo havde ret til at få de amerikanske domstole til at afprøve den juridiske korrekthed af deres tilfangetagelse. Det var en del af den såkaldte 'habeas corpus' ret, det drejede sig om - en meget gammel engelsk-amerikansk retsbestemmelse, som betyder, at man ikke kan fængsle folk, uden at de først har været stillet for en dommer. 'Habeas corpus' kan føres helt tilbage til det 12. århundrede og anses for at være en af de mest vigtige demokratiske rettigheder $\mathrm{i}$ den engelske og senere også den amerikanske historie og tradition.

Hermed tvang Højesteret Forsvarsministeriet til at se nærmere på Guantanamo-fangernes juridiske status, hvilket medførte, at ministeriet begyndte at løslade eller overføre flere af fangerne til andre fængsler. Blot fire måneder senere var 202 Guantanamo-fanger blevet løsladt, og i marts 2005 havde de resterende 558 fanger været igennem såkaldte 'Combatant Status Review Tribunals' (militære tribunaler bestående af tre officerer), som fastslog, at 520 af disse fanger måtte anses for at være 'enemy combatants' (illegale kombattanter).

Rasul-dommen blev fulgt op i juni 2008 af dommen i Boumediene $v$. Bush, i hvilken Højesteret igen slog Guantanamo-fangernes 'habeas corpus' rettigheder fast og samtidig underkendte Bush-regeringens argumenter om, at disse udenlandske fanger, som blev holdt fangen på ikke-amerikansk (men derimod cubansk) territorium under den mærkværdige betegnelse 'enemy combatants,' ikke behøvede at blive 
behandlet i øverensstemmelse med Geneve-konventionerne.

Dette førte igen til løsladelser. I maj 2008 var der ca. 270 fanger tilbage på Guantanamo. Ca. 60 af disse fanger står til løsladelse, men må indtil videre blive, hvor de er, fordi ingen vil tage imod dem. Advokater for nogle af de øvrige fanger har endvidere kunnet påvise, at flere af de beviser, regeringen har anført som grund til at holde disse fanger tilbage, er opnået under tortur - og ifølge amerikansk ret holder sådanne beviser ikke og kan i stedet føre til, at sager må opgives. Dette er dybt problematisk - ikke mindst, hvis det rent faktisk viser sig, at disse fanger har været medvirkende til terror. Der har den senere tid været indtil flere artikler i aviserne om, at denne eller hin Guantanmo fange, som netop måtte løslades, fordi beviser i hans sag var opnået under tortur, var taget direkte hjem for at genoptage terrorkampen mod Vesten med USA i spidsen.

I sin indsættelsestale undsagde Barack Obama på flere områder sin forgængers politik. Dette gjaldt ikke mindst i forhold til Guantanamolejren, som præsidenten agter at lukke snarest og helst inden for det næste år. Retssikkerhed og menneskerettigheder skal ikke længere ofres på terrorbekæmpelsens alter, mente Obama, og Geneve-konventionerne skal igen gælde fuldt ud for alle, USA tilbageholder interna- tionalt. I slutningen af februar 2009 konkluderede en Pentagon-rapport om forholdene i Guantanamo-lejren imidlertid, at forholdene for fangerne rent faktisk lever op til Genevekonventionerne. Rapporten anbefalede dog, at fangerne i de mest afsikrede områder af lejren skulle have mere adgang til socialt samvær og til at udføre religiøse handlinger. Rapporten er udarbejdet af admiral Patrick M. Walsh, som er næstkommanderende i den amerikanske flåde, og Obama havde selv bestilt den som led i planerne om at lukke lejren.

Få dage senere understregede justitsminister Eric Holder efter et besøg i Guantanamo, at selvom han var imponeret over den måde, hvorpå fængslet nu fungerer, havde Pentagon-rapporten ikke ændret ved hverken hans eller hans præsidents vilje til at lukke lejren. "It does not in any way decrease our determination to close the facility, even though ... it is being well-run now," sagde Holder. Vi kan kun håbe på, at Holder og Obama følger deres lands Højesteret i denne sag!

Professor dr.phil. Helle Porsdam er ph.d. $i$ American Studies fra Yale University. Helle Porsdam var tidligere ansat som professor ved SDU, men siden august 2008 har hun varet professor ved SaxoInstituttet, $K U$. 